\title{
Job Satisfaction as a Mediator of Emotional Intelligence and Transformational Leadership on Teacher Performance
}

\author{
Prakoso Agung Suryo ${ }^{1}$ Moh. Romadloni ${ }^{2} \quad$ Harianto Respati ${ }^{3}$ \\ 1.Students in Magister Management Program, University of Merdeka Malang, Indonesia \\ 2. STIMI Samarinda, Indonesia \\ 3.Economics and Business Faculty, University of Merdeka Malang, Indonesia \\ Corresponding Author: Harianto Respati \\ E-mail: patidarma@yahoo.com
}

\begin{abstract}
:
The purpose of this study is to examine the impact of emotional intelligence and transformational leadership style on teacher performance by considering aspects of job satisfaction. Four research variables were tested in structural equation models. This research is a causality study that measures the perceptions of high school teachers. Research design is quantitative, with a survey method. Likert scale questionnaire is used to collect respondents' perceptions. A total of 150 high school teachers as research populations. Sampling uses the census method. The explanation of causality between research variables is accessed by structural equation modeling. The results of the study showed that transformational leadership was more needed than the emotional intelligence of the teacher to realize the job satisfaction of teachers, which ultimately created discipline performance. Teacher job satisfaction is an effective consideration for management in high school to achieve teacher performance.
\end{abstract}

Keywords: emotional intelligence, transformational leadership. job satisfaction, teacher performance DOI: $10.7176 / \mathrm{EJBM} / 11-32-06$

Publication date: November $30^{\text {th }} 2019$

\section{INTRODUCTION}

School is a social institution for the development of human resources, which is needed for nation-building. For this reason, the process of education in schools must continue to be improved along with the greater global challenges in the era of globalization in the 21st century (Syafaruddin, 2008). Teacher performance is a keyword for the education process in Indonesia. The government sets standards for teachers (Teacher and lecturer law, 2003 and 2005)

As educators, of course, the teachers are required to have intellectual abilities so that the material is easily understood by students through an effective learning process (Hendriani and Lestari, 2013). The ability to transfer knowledge is part of the intellectual property of the teachers. It was stated again by Hendriani and Lestari (2013) that intellectual ability is not enough to indicate the level of one's intelligence. Besides intellectual intelligence, the teacher's emotions become a consideration for teachers, known as emotional intelligence. Emotional intelligence must be possessed by teachers to recognize themselves. Emotional stability makes it easy for teachers to learn and develop abilities gradually. This research wants to answer whether it is true that emotional intelligence has an impact on teacher performance.

Ealias and Jijo (2012) have explained that emotional intelligence and job satisfaction are two interesting concepts in this modern era. Regarding education, Ealias and Jijo (2012) have argued that teachers need to be satisfied when working, meaning that emotional intelligence that teachers have should be followed by feeling happy when working. The happy feeling of the teacher when working is part of job satisfaction, which is measured in this study. Khan et al. (2012) have examined the factors that influence job satisfaction in Pakistani medical institutions. The results of the research have shown that job satisfaction affects the performance of doctors and nurses. Related to the field of education, the teaching profession is relatively the same as medical personnel, who both require intellectual intelligence to succeed in professional work. This research tries to explain the relationship between intellectual intelligence, job satisfaction and teacher performance in high school. Is it true that a teacher's intellectual intelligence needs to lead to a level of job satisfaction and ultimately lead to teacher performance?. The results of this analysis are a solution for school leaders to understand the role of teachers in improving performance for the success of the education process and nation-building.

Then the research hypothesis is:

H1: Job Satisfaction mediates Intellectual Intelligence to develop teacher performance.

The effectiveness of implementing leadership includes how to convince someone. The nature of leadership is motivation, decision, communication, and control processes to create a conducive climate for educational policy (Jauch and Glueck, 1986). Hersey and Blanchard (1988) have proposed the situational theory, assuming that there is no right to lead with a particular style for all types of situations. In certain situations, a leader's behavior is divided into two dimensions, namely task-oriented behavior and the behavior of building interpersonal relationships of group members. The results of field study observations have found that many 
school leaders apply transformational leadership in a high school in Indonesia. Transformational leadership is done to influence teachers to have quality behavior in teaching activities. Transformational leadership focuses more on empowering human resources. There are four elements inherent in the transformational leadership style. Transformational leadership style by school leaders applies three things, namely intellectual stimulation, individual consideration, inspirational motivation, and idealized influence. Heather et al., (2001) have conducted research for educated medical personnel. The results of the research of Heather et al., (2001) have explained that leadership can drive the performance of medical employees. Thus Huda (2014) has examined transformational leadership at SME's, the results of the research have influenced employee performance. In the banking sector, Abouraia and Othman (2017) have examined the relationship between transformational leadership and job satisfaction in Dubai, the results of the study have shown significant influence. Job satisfaction is one aspect that can improve organizational performance, so it can be analogized that individual job satisfaction affects overall performance. Petty et al. (1984) have explained that there is a strong influence between job satisfaction and individual performance. This study tries to test the implementation of transformational leadership in creating teacher job satisfaction which ultimately affects teacher performance in high school.

Then the research hypothesis is:

H2: Job Satisfaction mediates transformational leadership to improve teacher performance.

This study examines two different conditions in the high school namely the emotional intelligence of high school teachers and transformational leadership styles by school leaders. These two conditions, which one most influences work satisfaction or teacher performance. If this is the case, it is necessary to test the aspects of job satisfaction on teacher performance. This event can be explained from the results of the structural equation model analysis. This testing process is carried out in structural equation models, where the results of this study can provide solutions for school leaders especially those who apply transformational leadership styles to improve the performance of teachers.

\section{LITERATURE STUDY}

a. Performance

Human resources (HR) have an important role in determining the success and achievement of company goals. To achieve the goal, resources are required to be able to increase work productivity for the sustainability of the organization. Improving employee performance creates the progress of the company to survive in the competitive situation of an unstable business environment. Therefore, efforts to improve employee performance are a management challenge. It all depends on the quality of human resource performance (Erza, 2012). Performance is a record of the results of activities over a period of time (Sudarmanto, 2014). Four performance measurements according to Bernardin and Russel (1993), namely performance according to the quality of work, quantity, the timeliness of completing work and coworker relations. Work quality shows the measure of performance expected by the company. Work quality results can indicate conformity or nonconformity. Qualitative measurement approaches subjective judgment. The quality of work shows the output of work results measured by the valuation method in the form of numbers. The work results in a quantitative view have a certain standard size. Timeliness is employees' work in accordance with the standard work time set by the company. This measure of performance is timeliness or target time for work. Performance results can be stated according to the target time or not in accordance with the target time. Co-worker relations is a performance that includes managing relationships with colleagues. Individual and group feelings are guidelines for measuring performance. The interpersonal impact is a level of employee's condition that creates a comfortable atmosphere in work, confidence, and cooperation between colleagues.

b. Job satisfaction

Job satisfaction as a complex emotional reaction (Sutrisno, 2009). This emotional reaction is a result of encouragement, desires, demands, and expectations of employees on work related to employee feelings. Thus, it creates a form of emotional reaction in the form of feeling happy, feeling satisfied or feeling dissatisfied. Another definition of job satisfaction is the attitude of employees to work associated with work situations, cooperation between employees, wages received, and things related to physical and psychological factors that are felt. Job satisfaction is the attitude or feeling of satisfaction and dissatisfaction of employees towards the results of the assessment of the work that has been done. This is in line with the opinion of Kaswan (2012) and Handoko (2001) to explain job satisfaction as a feeling of satisfaction or dissatisfaction of employees towards work. This feeling is indicated by the attitude of employees towards work. Kaswan (2012) and Luthans (2006) explain the measurement of job satisfaction consists of job satisfaction, wages and salaries received promotion/career opportunities, supervisory systems, and coworker situations.

c. Emotional Intelligence

According to Agustian (2009), emotional intelligence is the ability to understand emotions and 
sources of information to understand themselves and others, as a step towards achieving goals. Goleman (2000) defines emotional intelligence as "the ability to recognize our own feelings and the feelings of others, the ability to motivate ourselves, and the ability to manage emotions well in ourselves, and its relationship with others".

Emotional intelligence has certain components. the component of emotional intelligence according to Goleman (2015) consists of:

1) Self-awareness. The component of self-awareness as a teacher is their ability to know about themselves, observe themselves, recognize their own feelings, collect feelings vocabulary, accept themselves, recognize relationships between self, environment, and God, and recognize the relationship between ideas, feelings, and reactions.

2) Self-regulation. According to Goleman (2015), this aspect is the handling of feelings so that they can be revealed correctly. The self-regulation component covers several aspects. These aspects include: (1) The teacher is able to understand what is behind the feeling. (2) The teacher knows how to deal with anxiety, anger, and sadness, responsibility for decisions and actions, and follow-up agreements. This skill depends on self-awareness. (Goleman 2015).

3) Motivation. According to Goleman (2015) is managing emotions as a tool to achieve goals. It is very important to pay attention, to motivate yourself and master yourself, and to be creative. The selfcontrol of emotional feelings is the basis of success. That is, the teachers must be able to adjust, it will enable the realization of high performance in all fields. Thus, teachers who have these skills tend to be more productive.

4) Empathy. Empathy is an ability that depends on emotional self-awareness and is a social skill. Teachers who have good empathy will be more able to be sensitive to hidden social things, and able to signal what others need or want.

5) Social skills. Regarding social skills or building relationships with others, according to Goleman (2015), it is the skill of managing emotions in others. These skills support popularity, leadership and interpersonal success.

d. Transformational leadership

Transformational leadership is defined as leadership that involves changes in the organization. This leadership is also defined as leadership that emphasizes empowerment activities by increasing the positive self-concept of organizational members (Nawawi, 2006). Transformational leadership has an understanding of leadership that aims to change. In accordance with the rules of leadership, namely movements to achieve goals, what is meant here is change. The intended change is assumed to be a change in a better direction, opposing the status quo and being active (Lensufiie, 2010). Furthermore, to be able to produce productivity, transformational leadership has been defined as "Fours"' - Idealized influence, inspirational motivation, intellectual stimulation, and individualized consideration (Bass 1985). The dimensions of transformational leadership are as follows (Nawawi,2006; Yuk1, 2005):

1) Intellectual Stimulation.

Transformational leaders stimulate their subordinates' efforts to be innovative and creative by questioning assumptions, limiting problems and approaching the old situation in a new way, promoting the use of intelligence, prioritizing rationality and carrying out careful problem-solving.

2) Individual Consideration.

Transformational leaders have special attention to individual needs and growth that is expected to behave as a coach or mentor and provide advice.

3) Inspirational Motivation.

Transformational leaders aim to motivate and inspire people around them. Communicating with high expectations, using slogans to focus effort, expresses something important in a simple way. Everything is done so that other people are willing to follow

4) Idealized Influence.

Transformational leaders behave as models for their subordinates. Such leaders are usually respected, trusted, and charismatic because they have a clear vision and mission statement. Gaining support and trust from members of the organization and colleagues.

\section{RESEARCH METHOD}

a. Research design

This study uses a survey method that is collecting information from a large population.

The research approach is a positivist to answer the problem statement, the variables studied are quantitative and the data collection process uses an internal perceptional approach. The respondents of this study were 150 teachers in a Vocational High School in Malang, Indonesia. The sample has been set as many as 150 teachers so this study uses the census method. Characteristics of selected teachers 
are permanent teachers, honorary teachers, and practical teachers.

b. Data collection technique

Data collection using a questionnaire. Questionnaire answers using a Likert scale with a choice of 5 points. The highest point of 5 states the perception strongly agrees to the lowest point of 1 states strongly disagree, point 3 is a neutral choice. The data collected is tabulated, then tests the validity and reliability of the instrument.

c. Research model

The relationship between indicators and latent variables is reflective, so confirmatory factor analysis is needed for each variable assisted with the AMOS program. Exogenous variables of emotional intelligence (KE) are reflected by 5 indicators namely self-awareness, self-management, motivation, empathy and social skills. Exogenous variables of transformational leadership (KT) are reflected by 4 indicators: idealistic influence, individual consideration, inspirational motivation, and intellectual stimulation. Endogenous variables Teacher performance (KIN) is reflected by 4 indicators namely quantity, quality, attendance, and collaboration ability. Mediation variables job satisfaction (KT) are reflected 5 indicators namely satisfied with the leader, work, promotion, wages and satisfaction with co-workers.

Figure 1. Structural equation model

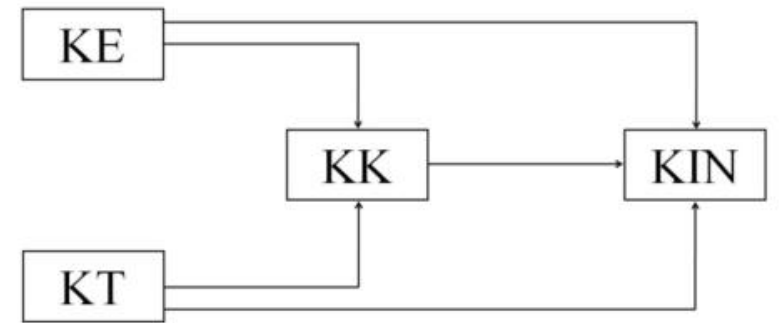

\section{RESEARCH RESULTS}

a. Characteristics of respondents

Most respondents were male, at the age level of 41 to 50 years. The level of education is a bachelor with tenure between 1-10 years. The conditions of these respondents indicated that they understood the duties and responsibilities in their work environment.

b. Factor loading test results.

The test results of the measured questionnaire items were declared valid and reliable. Next, a Confirmatory Factor test was performed for each research variable. Table 1 presents the factor loading values for each research indicator.

Table 1. Description of Factors Loading

\begin{tabular}{|l|l|l|l|}
\hline KE- Emotional Intelligence & Loading & KK- Job satisfaction & Loading \\
\hline X11 self-awareness & 0.79 & Y11- satisfied with the leader & 0.71 \\
\hline X12 self-management & $\mathbf{0 . 9 7}$ & Y12- work satisfaction & 0.70 \\
\hline X13 motivation & 0.88 & Y13- promotion satisfaction & 0.79 \\
\hline X14- empathy & 0.80 & Y14- wages upah satisfaction & $\mathbf{0 . 8 5}$ \\
\hline X15- social skills & 0.87 & Y15- co-workers satisfaction & 0.88 \\
\hline KT- Transformational leadership & & KIN- Teacher performance & \\
\hline X21- idealistic influence & 0.73 & Y21- quantity & 0.77 \\
\hline X22- individual consideration & 0.73 & Y22- quality & 0.75 \\
\hline X23- inspirational motivation & $\mathbf{0 . 9 6}$ & Y23- attendance & $\mathbf{0 . 8 9}$ \\
\hline X24- intellectual stimulation & 0.91 & Y24- collaboration ability & 0.87 \\
\hline
\end{tabular}

Table 1 shows that all the loading factors of the tested indicators are above 0.5 . This explains that indicators are proven to reflect research variables. Five indicators namely self-awareness, self-management, empathy, and social skills show can reflect emotional intelligence.

Four indicators such as idealistic influence, individual consideration, inspirational motivation, and intellectual stimulation can reflect transformational leadership

Five indicators such as satisfied with the leader, work satisfaction, promotions, wages, and coworkers can reflect job satisfaction.

Four indicators such as the quantity of work, the quality of work, attendance and the ability of teacher collaboration can reflect teacher performance.

c. Structural equation model test results 
The goodness of Fit evaluation has shown that the Chi-square value was 618,931 and the probability value was 0,000 less than 0.05 . However, the value of RMSEA $=0.053(\leq 0.08)$, GFI $=0.910(\geq 0.90)$, TLI $=0.953(\geq 0.95)$. Sanusi (2011) has explained that the model is declared eligible if one or two goodness of fit criteria meets the recommended cut-off value.

Based on the results of the statistical analysis of the equation model, it shows that the structural equation model that is constructed does not differ from the facts studied.

Thus, the structural equation model that has been built can be an analytical model to test the research hypothesis. The results of SEM analyses that have been accessed by the AMOS program are presented in Figure 2.

Figure 2. Coefficient of Structural Equation Modeling

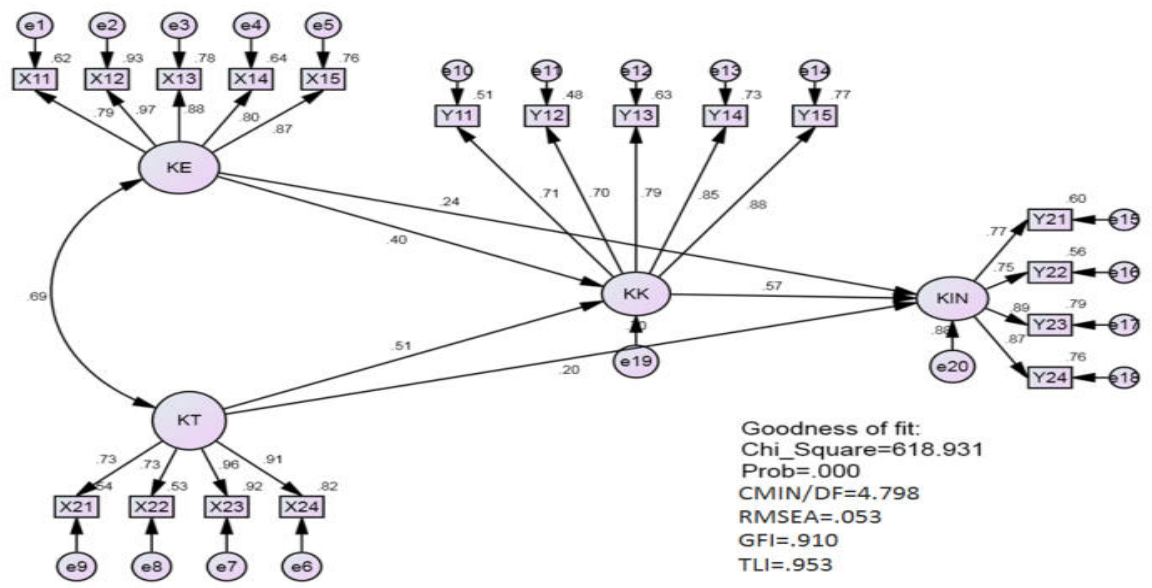

Note,

$\mathrm{KE}=$ Emotional Intelligence; $\mathrm{KT}=$ Transformational Leadership; KK $=$ Job Satisfaction; KIN = Teacher performance

The results of standardized coefficient testing between exogenous and endogenous variables are presented in Table 2. The results of the study have proven that all path coefficients of exogenous and endogenous variables have a significant effect. Hypothesis test results are presented in Table 2.

Table 2. Parameter estimates for the structural model

\begin{tabular}{|l|l|l|l|l|}
\hline Path & Direct path & $\begin{array}{l}\text { Indirect } \\
\text { Path }\end{array}$ & $\begin{array}{l}\text { Total } \\
\text { Path }\end{array}$ & Remarks \\
\hline KE $\rightarrow$ KK $\rightarrow$ KIN & $0.24^{*}$ & $0.40^{*} .0 .57^{*}=0.23^{*}$ & $0.24^{*}+0.23^{*}=0.47^{*}$ & $H 1$ supported \\
\hline $\mathrm{KT} \rightarrow \mathrm{KK} \rightarrow \mathrm{KIN}$ & $0.20^{*}$ & $0.51^{*} .0 .57^{*}=0.29^{*}$ & $0.51^{*}+0.29^{*}=0.80^{*}$ & $H 2$ supported \\
\hline
\end{tabular}

Note: ${ }^{*}$ ) significant of $\mathrm{p} \leq 0.05$

The total effect for three-variable models "KT influence on KIN mediated by KK" obtained a total path value of 0.80 greater than the total path value for three-variable models "the effect of KE on KIN mediated by KK". Based on the analysis of the strength of the path, it was found that KT was superior to influence by KK than KE, and there was a significant influence of KK on KIN. Thus, the three path variable model "KT influence on KIN mediated by KK" becomes the strongest path in the full structural equation model.

After that, comparing the indirect effect of "KT influence on KIN through KK" which was 0.29 with the direct effect of "KT influence on KIN" which was 0.20. This comparison has shown that the indirect effect is greater than the direct effect $(0.29>0.20)$.

The findings of the path analysis have proven that "the effect of KT on KIN through KK" is an effective model.

Path analysis to explain the position of the KK mediation variable can be explained that the KK variable is an effective supporter, compared to the "direct influence of KT on KIN".

\section{DISCUSSION}

Teacher emotional intelligence in daily activities can be observed from teacher attitudes such as self-awareness, 
self-management, teacher motivation, empathy abilities, and social skills. Among the five conditions of teacher's emotional awareness, it has been found that the ability of teachers to manage themselves is superior when compared to other indicators.

Measurement results for teacher transformational leadership have found that inspirational motivation can better reflect teacher leadership styles in high school.

The type of teacher satisfaction while working as a teacher has been more reflected in the satisfaction of receiving wages after carrying out work.

This means that the financial aspect is preferred by high school teachers. Teacher performance is more evident in the work activities of teachers especially when discipline is always present during working hours.

The relationship between the emotional intelligence of teachers and job satisfaction shows that the ability of teachers to regulate themselves leads to the efforts of teachers to obtain finance as a source of income. The teacher has the ability to self-regulate the work agenda in order to obtain a better income. Likewise, the impact of this ability to self-regulate has an impact on teacher performance levels.

The relationship between transformational leadership style in high school and job satisfaction that inspirational leadership style carried out by the principal affects the ability of teachers to obtain financial satisfaction, meaning that inspiration from the leader provides opportunities for teachers to be realized in activities that can generate financial income.

Likewise, the transformational leadership of school leaders has a positive impact on the level of teacher attendance. This finding supports the statement of Heather et al (2001) and Chen (2004) that leadership can improve employee performance.

The relationship between job satisfaction and teacher performance has been proven that there is an influence of job satisfaction on teacher performance. This means that financial satisfaction has a positive impact on school attendance. Handoko (2008) states that "employees who get job satisfaction usually have a better attendance record and regulations". The findings of this study support the opinion of Gibson (2006) that job satisfaction causes an increase in work performance so that satisfied workers will be more productive.

The core explanation of this discussion is the role of teacher job satisfaction is needed by organizations in schools. Teacher job satisfaction is caused by the success of the transformational leadership style. Teacher job satisfaction has a positive effect on teacher performance. Organizations that have more satisfied employees tend to be more effective than organizations that have less satisfied employees (Robbins, 2003).

\section{CONCLUSIONS AND RECOMMENDATIONS}

Job satisfaction of teachers in high schools, especially aspects of financial fulfillment is the key to success in the behavior of the presence of teachers to work at school. This happens because of the implementation of a transformational leadership style in which the leader always provides inspiration to teachers to behave productively as teaching staff. The findings of this study indicate that income is an important aspect of teachers for teachers. Adequate financial needs are highly expected by the teacher. Hence, high school leaders always inspire teachers to be creative in finding extra income. Through this transformational leadership style that is focused on this aspect of inspirational motivation causes teachers to do creative work. Creative work becomes successful if there is a teacher's ability to manage themselves through the teacher's personal agenda.

So that these two things together, such as inspirational transformational leadership and emotional selfcontrol a teacher becomes important to create job satisfaction through the acquisition of income which ultimately leads to disciplinary performance.

This research has not measured aspects of teacher work culture as a cause of teacher job satisfaction. A work culture that is followed by a high work ethic certainly has an impact on disciplinary performance. Therefore, it is also necessary to examine the impact of job satisfaction on disciplinary performance with a high work ethic strategy for teachers or educators who are equal to the teacher. That is, a high work ethic strategy becomes a mediating variable.

\section{References}

Abouraia, Mahmoud Kamal and Saad Mohammed Othman.2017. Transformational Leadership, Job Satisfaction, Organizational Commitment, and Turnover Intentions: The Direct Effects among Bank Representatives. American Journal of Industrial and Business Management, Vol 7.pp. 404-423

Agustian, Ary Ginanjar. 2009. The Secret to Success in Building ESQ Emotional and Spiritual Intelligence: Emotional Spiritual Quotient, Jakarta: ARGA Publishing.

Bass, B. M.1985. Leadership and Performance Beyond Expectations. New York: Free Press.

Bernaddin, H.J., and Rusell, JEA. (1993). Human Resources Management. New York: Mc. Graw Hill, inc.

Chen, Jui-Chen., Colin Silverthorne, and Jung-Yao Hung.2004.Organization Communication, Job Stress, Organizational Commitment and Job Performance of Accounting Professionals In Taiwan and America. Leadership and Organizational Journal. 27 (4), p.242-249 
Chen, C. K. 2004. Research on the impacts of team leadership on team effectiveness. The Journal of American Academy of Business. Cambridge, pp.266-278.

Ealias, Abi and Jijo George. 2012. Emotional Intelligence and Job Satisfaction: A Correlational study. Research journal of Commerce \& Behavioral Science. Vol 01.No.04

Erza, R.N. 2012. The influence of leadership, motivation and work discipline on the performance of the employees in PT Sinar Lestari, Pekanbaru.

Gibson, Goustimo Cardoso. 2006. Human resource management. Yogyakarta. Andy Offset.

Gibson, J.L. Ivan C and Donnelly, J.P. 2006. Organization: Behavior, Structure, Process. Eighth Edition. Subtitles: Agus Dharma. Jakarta: Erlangga Publisher

Goleman, Daniel. 2000. Emotional Intelligence. PT Gramedia Pustaka Utama. Jakarta

Handoko, T. Hani. 2008. Personnel Management and Human Resources. BPFE. Yogyakarta.

Heather, Laschinger.,K. Spence, Joan Finegan, and Judith Shmian. 2001. The Impact of Workplace Empowerment, Organizational Trust on Staff Nurses Work Satisfaction and Organizational Commitment, Health Care Manage Rev., Aspen Publisher. Inc

Hadrian, Susi and Raden Lestari Garnasih. 2013. The Influence of Intellectual Intelligence and Emotional Intelligence on the Performance of Teachers of SMAN 8 Pekanbaru. Jurnal Ekonomi. Vol. 21. No. 4

Hersey, P., and Blanchard KH. 1986. Management: Organizational Behavior. McGraw Hill. Singapura.

Huda, Machwal. 2014. The Influence of Work Culture, Transformational Leadership and the Work Environment on Work Motivation and Performance of employers of cooperatives in the bag and luggage industry subsector in Sidoarjo Regency. Tesis. UNMER : Malang

Jauch, Laurance R., and William Glueck.1988. Business Policy and Strategic Management. Singapura. McGraw Hill.

Kaswan. 2012. Human Resource Management for Organizational Competitive Advantage. Graha ilmu. Yogyakarta

Khan, Alamdar Hussain., Muhammad Musarrat Nawaz., Muhammad Aleem., and Wasim Hamed. 2012. Impact Of Job Satisfaction On Employee Performance: An Empirical Study Of Autonomous Medical Institutions Of Pakistan. African Journal Of Business Management.Vol. 6 No.7. pp. 2697-2705

Lensufiie, Tikno. 2011. Leadership for Professionals and Students. Erlangga. Jakarta.

Luthans, Fred. 2006. Organizational Behavior, 10th edition.Penerbit Andi. Yogyakarta.

Nawawi, Hadari. 2006. Performance evaluation and management in corporate and industrial environments. Gadjah Mada University Press. Yogyakarta.

Petty, M.M., Gail W., Mc Gee., and Jerry W. Cavender., 1984. A Meta - Analysis of the Relationship Between individual Job Satisfaction and Individual Performance. Academy of Management Review. Vol 9 . No 4 p.712-721

Robbins, S. P.2003. Organizational Behavior: Concepts, Controversies, Applications. The eighth edition of the Indonesian version. : PT Prenhallindo. Jakarta.

Sudarmanto. 2014. HR Competency Performance and Development (Theory, Measurement Dimensions, and Implementation in Organizations). Pustaka Pelajar. Yogyakarta:

Sutrisno, Edy. 2009. Human Resource Management. Kencana. Jakarta.

Syafaruddin.2008. Effectiveness of Educational Policy: Concepts, Strategies and Application of Policies towards Effective School Organizations. Rineka Cipta. Jakarta.

Teacher and lecturer law, 2003. UU Nomor 20 Tahun 2003: Sistem Pendidikan Nasional.

Teacher and lecturer law, 2005. UU Nomor 14 Tahun 2005: Guru dan Dosen. 